\title{
Market reactions to dividends announcements and payouts. Empirical evidence from the Warsaw Stock Exchange
}

\author{
Urszula Mrzygłód', Sabina Nowak²
}

ABSTRACT

The main goal of this paper is the empirical examination of the Polish stock market reactions to dividend announcements and dividend payouts made by the companies listed on the Warsaw Stock Exchange (WSE). The research sample comprises 56 companies (WIG index constituents) that announced dividend payments and completed the payout during 2013. In the analysis, event study methodology is employed including either calculating abnormal returns and cumulative abnormal returns around the event day or testing their statistical significance using parametric and nonparametric tests. The average cross-sectional abnormal return calculated for the entire sample is found to be significant on the dividend announcement day $(t=0,0.86 \%)$ and on one day after $(t=+1$, $0.59 \%)$ at the $1 \%$ and $10 \%$ significance levels, respectively. The outcomes of the analysis conducted within the three distinguished subsamples are rather more diverse. In the subgroup of the first announced dividends (or dividends announced after a minimum one-year break), the significant average abnormal return is found on day $t=+1(0.90 \%$, $5 \%$ significance level), whereas in the case of the dividend decreases subsample, the significant average abnormal returns (at the 10\% significance level) occur on days $t=-4(-1.44 \%)$ and $t=+2(-1.15 \%)$. The average abnormal return calculated within the subsample of dividend increases turns out to be positive and significant on day $t=+1$ (1.03\%, 10\% significance level). The results obtained for the average cumulative abnormal returns corroborate the findings reached for the average cross-sectional abnormal returns in the case of the first dividend and dividend increase subsamples. However, the average cross-sectional abnormal returns calculated within the eleven-day-long event window around the dividend payment day turn out to be statistically insignificant. The obtained results provide evidence that the Polish stock market reaction to dividend announcements is positive and immediate. However, the market does not significantly react to dividend payouts, which may lead to the conclusion that the WSE directly incorporates news on dividends into stock prices. Moreover, the reaction of the market for dividend announcements is consistent with the sign of the dividend change: dividend-increase (-decrease) announcements are interpreted as a positive (negative) signal by the investors. Such results support both the informational content of the dividend hypothesis and the dividend signaling hypothesis. Considering that the observed abnormal market behavior disappears within two days at most after the announcement date, the results of the study can be useful for financial practitioners only with regard to short-term investment decisions.

KEY WORDS: $\quad$ dividends, stock prices, event study, Warsaw Stock Exchange

JEL Classification: G14

${ }^{1}$ University of Gdansk - Institute of International Business, Poland; ${ }^{2}$ University of Gdansk - Department of Econometrics, Poland

Correspondence concerning this article should be addressed to: Sabina Nowak, University of Gdansk - Department of Econometrics, Armii Krajowej 101, Sopot 81-824, Poland. E-mail: sabina.nowak@ug.edu.pl 


\section{Introduction}

The issue of payout policy is of great importance for companies' managers and remains one of the most interesting problems in theoretical and empirical finance. Since Lintner's (1956) and Miller and Modigliani's (1961) original papers, a number of theories, which often have divergent views on the determinants and consequences of dividend payouts, were developed and empirically investigated. A consensus, however, has not been reached, and we still do not know exactly why companies choose to pay dividends. In prior studies, the problem of stock price responses to dividend announcements has attracted particular attention. Regardless of the predictions of the Miller and Modigliani (1961), dividend irrelevance hypothesis, the previous studies on the developed markets confirm that stock markets do react to dividend announcements. Thus, dividends convey valuable information for shareholders about the future prospects of the companies and can be a valuable tool used by managers to signal the financial condition of the companies.

Although these questions of fact have been the subject of the extensive research on mature markets, less attention has been paid to the emerging stock markets. The literature regarding those markets is rather limited, and the conclusions remain ambiguous. Thus, it is justified to investigate dividend announcement and payout effects on the behavior of the Polish stock market.

The aim of the paper is to investigate the stock market reaction to dividend announcements and dividend payouts made by companies listed on the Polish stock market, namely, the Warsaw Stock Exchange (WSE). The research is based on a sample of 56 companies that announced dividend payments and completed the payouts in 2013. In the analysis, the event study methodology is employed.

In addition to the main goal of the paper, the reactions of the stock market among different groups concerning dividend announcements are investigated. Similar to other studies, groups were distinguished by comparing the dividend level in 2013 to the previous year. Thus, the sample was divided into three groups: a) first dividend announcement or announcement of dividend resumption after a minimum one-year break, b) dividend-decrease announcement, c) dividend-increase announcement.
In the present paper, we make three contributions to the existing literature on the Polish stock market. First, we treat the first official recommendation containing information of the dividend amount as the date of announcement. The present study differs from prior studies that equated the dividend announcement day with the date of the annual shareholders meeting. Second, we concentrate only on the effect of dividend announcements by clearing the dataset and removing the earning announcements. Third, we not only employ common parametric tests to verify the results, but we also recognize the distribution of the stock returns and introduce nonparametric tests when needed.

The remainder of the paper is organized as follows. In section 2, a concise literature review regarding the impact of dividend announcements and payouts on stock prices is presented. In section 3, the Polish stock market is briefly characterized, and results from previous studies conducted on companies listed on WSE are presented. In section 4 , the outline of empirical design is described, while in section 5 , the results of the research are discussed. In the last section, the conclusions and implications for further research are presented.

\section{Literature review}

The relevance or irrelevance of dividend policy to the market value of shares has been one of the most discussed topics in the financial literature since the pioneering works of Lintner (1956) and Miller and Modigliani (1961). In the latter paper, the reasoning is conducted under three important assumptions: perfect capital markets, investors' rational behavior and investors' perfect certainty. The authors conduct the analysis for a single type of financial instrument, namely, stocks (Miller \& Modigliani, 1961), and prove that with a given investment policy, the dividend policy cannot influence either the company's valuation or the shareholders' total return (the dividend irrelevance hypothesis). In Miller and Modigliani's ideal world, investors are indifferent between receiving dividends (cash payments) or capital gains (the rise in stock prices) as a source of wealth augmentation. In their paper (1961), Miller and Modigliani refer also to the fact that dividend decisions are often accompanied by changes in the share prices and introduce the so called 'informational content of dividends'. However, the authors explain that if the company had conducted stable 

In their more recent paper, Baker and Wurgler (2012) also rely on prospect theory findings and argue that investors assess current dividends against past dividends, which serve as a 'psychological reference point'. Furthermore, Baker and Wurgler (2012) develop a multi-period dividend model that is consistent with the empirical findings of dividend announcements (the signaling effect of dividends) and explains the observed managers' behavior of 'dividend smoothing' (Linter partial adjustment model).

The market reactions to dividend announcements were examined in numerous empirical studies, which were mostly focused on large, developed stock markets (e.g., USA). In recent years, less developed stock markets have also received greater attention, and thus, the results have become more diverse.

Most empirical studies confirm the existence of the positive relationship between dividend announcements and stock price movements. The classic Pettit's (1972) study based on a sample of 625 companies listed on the NYSE in the period of 1964-1968 proves that dividends carry valuable information. Pettit divides the dividends dataset into seven categories: omissions, reductions, no change, initial payment, less than $10 \%$ increase, $10-25 \%$ increase, $25 \%$ or higher increase, whereas the initial payment group comprised companies that paid no dividend in the previous period. Pettit confirms that an increase (decrease) in dividends induces positive (negative) abnormal returns. It is pertinent to note that the major conclusions are drawn based on the monthly price data. Pettit additionally examines a much smaller sample of the daily stock returns (approximately equal to $10 \%$ of the monthly data sample) and finds that the market discounted the information within one day after the announcement. The author is aware that in such studies, the effect of related market information (i.e., earning announcements) must be excluded or at least considered. However, his proposal for overcoming this problem seems to be somewhat ambiguous and does not prevent the influence of the earnings announcements on the obtained results. Contemporary research devoted to the market price reactions should be conducted basing on time series data of at least daily intervals. The results obtained by Pettit are under discussion in later studies - see i.a. Dasilas and Leventis (2011) or Al-Shattarat, Al-Khasawneh, and Al-Shattarat (2012).
Similar to Pettit's work, Aharony and Swary (1980) also divide dividend announcements into subsequent subsets: no change in dividends, dividend increase, and dividend decrease. The sample covers 149 companies listed on NYSE in the period 1963-1976. Contrary to Pettit's study, the authors concentrate on daily data and introduce a method of grouping the earnings and dividend announcements according to the sign of dividend changes and the number of trading days between both types of announcements. Thus, Aharony and Swary (1980) obtain clear and mutually exclusive groups of announcements. Moreover, cases in which an earnings disclosure preceded (or followed) the dividend announcement are examined separately. In the case of a dividend increase, Aharony and Swary (1980) confirm significant abnormal returns on the day of dividend announcement and the day before. Moreover, in the cases of negative changes in dividends, the authors confirm significant negative abnormal returns whereas stable dividends give mixed and statistically insignificant results.

The effect of the first (initial) dividend announcement and an announcement after a long 'non-dividend' period is investigated by Asquith and Mullins (1983) on a sample of 168 companies listed on the NYSE or ASE for the period 1963-1980. The authors assume that dividend announcements are unexpected by market participants (see also Gurgul, Mestel, \& Schleicher, 2003). As Asquith and Mullins report, for almost $70 \%$ of companies, there was a positive market reaction to the initial dividend announcement. Asquith and Mullins additionally control for the effects of other important events that might have influenced the results and conclude that dividends convey unique information to investors. The authors also find support for the hypothesis that dividends and earnings announcements can be partial substitutes. However, the results may be disturbed by an unequal division of the announcements into the analyzed subsamples.

The joint impact of dividend announcements on stock and bond prices is investigated by Dhillon and Johnson (1994). The authors aim at distinguishing between two hypotheses, namely: the information content (1) and wealth redistribution (2). Dhillon and Johnson collect data on dividend announcements and bond prices for companies traded on NYSE and AMEX for the period 1978-1987 and introduce the 

of dividend cuts. Stable dividends are not followed by any statistically significant price reaction. Moreover, in the analysis of the German stock market (310 dividend announcements), with respect to larger and smaller companies, the author confirms abnormal trading volume during the announcement day irrespective of the dividend level (higher, lower, stable) (Gurgul, 2012).

The same definition of dividend announcement as Gurgul et al's (2003) is also adopted in the Dasilas and Leventis (2011) study devoted to the Greek stock market. Additionally, the authors decide to eliminate all events that could interfere with dividend announcements, such as news on earnings and stock splits, etc. Thus, based on 231 events, Dasilas and Leventis (2011) confirm significant price reactions to dividend announcements (increases and decreases). The statistically significant stock price movements on the dividend announcement day are also confirmed on the sample of 50 Irish companies in the 15 years' time span (McCluskey, Burton, Power, \& Sinclair, 2006). Unlike in other studies, the authors solely concentrate on those companies that announced simultaneously (on the same day) the earnings and dividend decisions. In the conclusion, McCluskey et al. (2006) discover that the earnings news are more important for investors than the dividend announcements.

To summarize, in most of the studies discussed above, the dividend announcement day is defined as the annual shareholders meeting day. In the present paper, we decided to follow the methodology of Gurgul et al. (2003) and adopt the date of the first official recommendation containing information of the dividend amount as the date of the dividend announcement. In addition, considering the problem of the small sample size that occurred in several studies, we concentrate solely on the impact of dividend announcements on stock prices and do not introduce a further sample division regarding the earnings announcements and companies' performance.

\section{Evidence from the Warsaw Stock Exchange}

The history of the Polish stock market is rather short since it was only re-established in 1991 together with market reforms introduced in Poland (ZiarkoSiwek, 2008, p. 347). The main motive prevailing in the construction of the WSE was to enable smooth privatization processes to aid in effective capital allocation, as Janicka (2005) notes. Since its establishment, the WSE has experienced growth in terms of capitalization and number of companies listed, and currently is a recognized regional stock market (see also Mrzygłód \& Nowak, 2013). However, it is worth noting that the WSE remains a relatively small market in comparison to the highly-developed US, German and UK stock exchanges. Moreover, by some global market players, such as the MSCI (Morgan \& Stanley Capital International), the WSE is identified as an emerging stock market.

The short history of the Polish stock market and the fact that the market remains in a developing stage influences, in the authors' opinions, the dividend policy of companies. Gurgul and Majdosz (2005) indicate that generally Polish companies do not follow a formal and transparent dividend policy. In our opinion, while the market is becoming more mature and companies are progressing to the next stage of the life-cycle, the empirical studies devoted to dividend effects are becoming even more justified.

Among prior studies concentrated on the Polish stock market, Gurgul and Majdosz (2005), Tuzimek (2012; 2013), Pieloch-Babiarz (2014) and Czekaj (2014) examine the impact of dividend announcements on stock prices. The stock market reaction is also investigated by Perepeczo $(2013 ; 2014)$. In those two latter studies however, the time series of cumulative abnormal returns fail to comply with normal distribution. Thus, results being based on parametric tests, although promising, are inconclusive.

Based on 45 dividend announcements within the period 2000-2004, Gurgul and Majdosz (2005) confirm the positive reaction of the stock market $(+0.79 \%)$ on the day after news release $(t+1)$. Contrary to studies on the US and European markets, Gurgul and Majdosz (2005) assume that any announcement concerning dividend payment should be treated as positive information for investors. Additionally, the authors examine the stock price reaction of the company's rivals coming from the same sector of the economy and reveal that industry rivals also experience positive stock price movements on the second day after announcement $(t+2)$.

The larger sample of dividend events (245) is employed in the Tuzimek's study (Tuzimek, 2013, pp. 275- 

definition of the event day: assuming that the event day and dividend payment day are equal, it does not fulfil any of the four conditions obligatory for event study proposed by Tabak and Dunbar (1999), namely, 'there is no reason to believe that the market anticipated the news'. However, the decision of analyzing the market response for the dividend payment in itself is dictated by the curiosity of whether the Polish market quickly incorporates the news into stock prices.

In the first stage of the research, the analysis of the abnormal returns and the cumulative abnormal returns performance within the event window $(-5,+5)$ days around the dividend announcement day and the dividend payment day in the entire sample is conducted.

In the next stage of the research, the stock price reactions conditioned on the direction of announced changes in expected dividend payouts are examined. To this end, the entire sample of dividend announcements is divided into four subsamples relating to the a) first dividend announcement or announcement of dividend resumption after a minimum one-year break (sample size: 18), b) dividend-decrease announcement (13), c) dividend-increase announcement (19) and d) constant-dividend announcement (6). Due to the small size of the $4^{\text {th }}$ subsample, it is omitted in further calculations.

In this study, the standard event study methodology is employed. The calculation is conducted based on daily data of stock prices derived from the official WSE website, gpwinfostrefa.pl. The actual daily stock return for $i$ company is calculated as follows:

$R_{i t}=\ln \left(\frac{P_{i t}}{P_{i t-1}}\right)$

where $P_{i t}\left(P_{i t-1}\right)$ indicates closing price for $i$ share on day $t(t-1)$.

The basic event period comprises 11 days around the dividend announcement (or payment) date, which gives the event window equal to $(-5,+5)$ days around day $t=0$.

The abnormal return $A R$ is defined as the market adjusted return

$A R_{i t}=R_{i t}-R_{M t}$

where $R_{M t}$ is the rate of return of market index reflected by WIG index. Adopting the abnormal return as the market adjusted return instead of calculating it based on market model, namely, $A R_{i t}=R_{i t}-\hat{\alpha}-\hat{\beta} \cdot R_{M t}$, is related either to the problem with time-varying parameters in the market model or to the high probability of not fulfilling the classical OLS assumptions in the case of using the daily data in estimation of the model parameters. However, computing abnormal returns according to equation (2) does not require using the estimation window, which eventually excludes the possibility to improve the properties of selected parametric tests, which will be discussed in detail below.

The average cross-sectional daily abnormal return is computed as follows:

$A \bar{R}_{t}=\frac{1}{N} \sum_{i=1}^{N} A R_{i t}$

where $N$ indicates the number of observations used in the study. The null hypothesis maintains that the abnormal return on day $t$ within the event window is equal to zero:

$H_{0}: E\left(A R_{t}\right)=0$

which means that the considered event has no influence on stock prices behavior. This hypothesis can be tested using the parametric test based on the ratio of cross-sectional mean abnormal returns and the standard deviation

$t=\frac{A \bar{R}_{t}}{\hat{\sigma}\left(A R_{t}\right)} \sqrt{N}$

where $\hat{\sigma}\left(A R_{t}\right)=\sqrt{\frac{1}{N-1} \sum_{i=1}^{N}\left(A R_{i t}-A \bar{R}_{t}\right)^{2}}$. Assuming that the abnormal returns are independent, identically distributed and normal, the t-statistic has a Student- $t$ distribution with $N-1$ degrees of freedom under the null hypothesis. With a similar procedure of verification, the statistical significance of the average crosssectional cumulative abnormal returns is subsequently conducted.

The cumulative abnormal return is calculated as follows:

$\operatorname{CAR}_{i}\left(t_{1}, t_{2}\right)=\sum_{t=t_{1}}^{t_{2}} A R_{i t}$ 
where $t_{1}$ and $t_{2}$ are the days chosen within the eleven days long event window. Consequently, the average cross-sectional cumulative abnormal return is equal to

$$
C \bar{A} R\left(t_{1}, t_{2}\right)=\sum_{i=1}^{N} C A R_{i}\left(t_{1}, t_{2}\right)
$$

where $N$ indicates the number of observations used in the study.

However, daily returns (either actual or abnormal) are, in general, not normally distributed; according to the standard central limit theorem, the cross-sectional mean excess return converges to normality with the increase in the number of securities. Otherwise, the usage of statistic (5) has a different limitation: the event occurrence on day $t$ usually leads to the contemporaneous changes of the numerator and denominator of the expression (5). Thus, it can lead to the situation when the t-statistic remains statistically insignificant, although the event considerably determines the stock prices (Gurgul, 2012, p. 51). Regrettably, equating abnormal returns to market adjusted returns instead of excessive returns over the market model impedes either employing the standard deviation of abnormal returns computed for estimation window (Gurgul, 2012, p. 51) or calculating the standardized abnormal returns and using parametric test proposed by Boehmer, Masumeci and Poulsen (1991).

Taking the asymmetry of the cross-sectional abnormal return distribution into account, the nonparametric Corrado's rank test (Corrado, 1989) and the generalized sign test are conducted. The first one is based on the statistic

$T(u)=\frac{\frac{1}{N} \sum_{i=1}^{N}\left(K_{i t}-\bar{K}\right)}{s(K)}$

where $K_{i t}$ denotes the rank of the abnormal return of $i$ security in period $t, t=1,2, \ldots, T, \bar{K}$ is the average rank calculated as $\bar{K}=\frac{1+T}{2}, s(K)$ denotes the standard deviation of ranks computed expressed as

$s(K)=\sqrt{\frac{1}{T} \sum_{t=1}^{T}\left[\frac{1}{N} \sum_{i=1}^{N}\left(K_{i t}-\bar{K}\right)\right]^{2}}$.
Under the null hypothesis expressed as (4), statistic $T(u)$ is distributed asymptotically as unit normal, $T(u) \sim N(0,1)$.

The generalized sign test is used to check whether the abnormal returns are independent across stocks. Under the null hypothesis of no abnormal performance, the number of positive and negative abnormal returns equals to 50 percent in the event window. The number of non-negative values of abnormal returns has a binomial distribution with parameter $p$ (Brown \& Warner, 1980; Cowan, 1992). The statistic for the sign test is defined as follows:

$z=\frac{p_{0}-p}{\sqrt{p(1-p) N}}$

where $p_{0}$ denotes the observed fraction of positive returns in the event period. Under the null hypothesis, $z \sim N(0,1)$.

\section{Results}

The results describing abnormal returns performance within the event window $(-5,+5)$ days around the dividend announcement day in the entire sample are summarized in Table 1.

The mean cross-sectional abnormal returns are positive and significantly different from zero either on the dividend announcement day $(t=0 ; 0.86 \%)$ or the day after the announcement $(t=+1 ; 0.59 \%)$. Shapiro-Wilk statistics reveal that the daily stock returns on days $t=-3, t=-2, t=-1, t=0, t=+3$ and $t=+4$ within the event window are not normally distributed.

Table 2 contains the summary of abnormal returns behavior within the event window around the dividend payment day.

In this case, mean cross abnormal returns are found to be statistically insignificant for all 10 days around the day the dividend was paid. The results of the Shapiro-Wilk test represent significant departures from normal distribution of majority abnormal returns within the event window. The cumulative abnormal return (CAR), which is calculated in the event window around the dividend announcement day, is approximately 3.5 times as large as the CAR calculated around the dividend payment day.

The results obtained for the average abnormal returns calculated within the entire sample are con- 
Table 1. Summary statistics for cross-sectional daily abnormal returns around dividend announcement day

\begin{tabular}{|c|c|c|c|c|c|c|c|c|c|}
\hline day $t$ & $\begin{array}{c}\min \\
A R_{t}\end{array}$ & $\begin{array}{c}\max \\
A R_{t}\end{array}$ & $A \bar{R}_{t}$ & $\hat{\sigma}\left(A R_{t}\right)$ & t stat. & skewn. & kurtosis & $\begin{array}{l}\text { SW } \\
\text { stat. }\end{array}$ & p-value \\
\hline-5 & -0.0686 & 0.0792 & 0.0035 & 0.0265 & 1.0032 & 0.3251 & 1.3395 & 0.9484 & 0.0180 \\
\hline-4 & -0.0758 & 0.0773 & -0.0042 & 0.0279 & -1.1240 & -0.1091 & 1.2035 & 0.9641 & 0.0936 \\
\hline-3 & -0.0467 & 0.0748 & 0.0016 & 0.0212 & 0.5541 & 1.0967 & 3.2196 & 0.9213 & 0.0013 \\
\hline-2 & -0.0583 & 0.0485 & -0.0019 & 0.0220 & -0.6579 & 0.1797 & 1.0318 & 0.94 & 0.0078 \\
\hline-1 & -0.0718 & 0.1025 & 0.0008 & 0.0263 & 0.2252 & 0.5529 & 3.9329 & 0.9254 & 0.0019 \\
\hline 0 & -0.0294 & 0.0934 & $0.0086^{* * *}$ & 0.0223 & 2.8741 & 1.1700 & 2.6928 & 0.9318 & 0.0035 \\
\hline 1 & -0.0725 & 0.0572 & $0.0059^{*}$ & 0.0251 & 1.7558 & -0.2364 & 0.8626 & 0.9741 & 0.268 \\
\hline 2 & -0.0502 & 0.0514 & -0.0017 & 0.0200 & -0.6455 & -0.1463 & 0.7689 & 0.9741 & 0.2702 \\
\hline 3 & -0.048 & 0.0744 & 0.0006 & 0.0244 & 0.1912 & 1.1880 & 2.4397 & 0.8921 & 0.0001 \\
\hline 4 & -0.0552 & 0.0411 & -0.0014 & 0.0209 & -0.5047 & -0.7515 & 0.4938 & 0.9383 & 0.0066 \\
\hline 5 & -0.0539 & 0.0478 & -0.0015 & 0.0190 & -0.5778 & 0.1335 & 1.5055 & 0.9594 & 0.0569 \\
\hline CAR & - & - & 0.00697 & & & & & & \\
\hline
\end{tabular}

Note: ${ }^{*}{ }^{* * *}$ - significance at the $10 \%, 1 \%$ significance level.

Table 2. Summary statistics for cross-sectional daily abnormal returns around dividend payment day

\begin{tabular}{|c|c|c|c|c|c|c|c|c|c|}
\hline day $t$ & $\min _{A R_{t}}$ & $\begin{array}{c}\max \\
A R_{t}\end{array}$ & $A \bar{R}_{t}$ & $\hat{\sigma}\left(A R_{t}\right)$ & t stat. & skewn. & kurtosis & $\begin{array}{l}\text { SW } \\
\text { stat. }\end{array}$ & $p$-value \\
\hline-5 & -0.0809 & 0.0735 & -0.0005 & 0.0271 & -0.1477 & 0.0321 & 2.6646 & 0.9038 & 0.0003 \\
\hline-4 & -0.1267 & 0.0708 & 0.0014 & 0.0287 & 0.3673 & -1.6244 & 7.4620 & 0.8378 & 0.0000 \\
\hline-3 & -0.0943 & 0.0687 & -0.0028 & 0.0288 & -0.7275 & -0.5454 & 1.7503 & 0.9603 & 0.0586 \\
\hline-2 & -0.0576 & 0.0491 & -0.0013 & 0.0210 & -0.4831 & -0.3887 & 0.5168 & 0.9824 & 0.5705 \\
\hline-1 & -0.0489 & 0.1184 & -0.0002 & 0.0255 & -0.0574 & 1.7334 & 7.2616 & 0.8772 & 0.0000 \\
\hline 0 & -0.0874 & 0.0565 & -0.0009 & 0.0244 & -0.2777 & -0.2677 & 2.5614 & 0.9346 & 0.0042 \\
\hline 1 & -0.0543 & 0.1010 & 0.0043 & 0.0251 & 1.2875 & 0.8844 & 4.0279 & 0.9145 & 0.0007 \\
\hline 2 & -0.0637 & 0.0933 & 0.0009 & 0.0268 & 0.2607 & 0.7234 & 2.8391 & 0.9342 & 0.0040 \\
\hline 3 & -0.0666 & 0.0670 & 0.0043 & 0.0273 & 1.1965 & 0.1286 & 0.9117 & 0.9613 & 0.0655 \\
\hline 4 & -0.0790 & 0.0654 & 0.0025 & 0.0238 & 0.7916 & -0.4173 & 2.3122 & 0.9404 & 0.0074 \\
\hline 5 & -0.0910 & 0.0456 & -0.0028 & 0.0224 & -0.9538 & -1.2011 & 3.5796 & 0.9319 & 0.0032 \\
\hline CAR & - & - & 0.00204 & & & & & & \\
\hline
\end{tabular}


Table 3. Statistical significance of the average cross-sectional cumulative abnormal returns $(C \bar{A} R s)$ around the dividend announcement and dividend payment day

\begin{tabular}{ccccccc}
\hline & \multicolumn{3}{c}{ dividend announcement day } & \multicolumn{3}{c}{ dividend payment day } \\
\cline { 2 - 6 }$\left(\boldsymbol{t}_{1}, \boldsymbol{t}_{2}\right)$ & $\overline{C A} R$ & $\hat{\sigma}\left(C A R_{t}\right)$ & $\mathrm{t}$ stat. & $C \bar{A} R$ & $\hat{\sigma}\left(C A R_{t}\right)$ & $\mathrm{t}$ stat. \\
\hline$(-5,0)$ & -0.0002 & 0.0587 & -0.0280 & -0.0034 & 0.0645 & -0.4032 \\
$(-4,0)$ & -0.0038 & 0.0497 & -0.5672 & -0.0029 & 0.0598 & -0.3680 \\
$(-3,0)$ & 0.0004 & 0.0384 & 0.0828 & -0.0043 & 0.0491 & -0.6635 \\
$(-2,0)$ & -0.0011 & 0.0357 & -0.2393 & -0.0015 & 0.0351 & -0.3297 \\
$(-1,0)$ & 0.0008 & 0.0263 & 0.2252 & -0.0002 & 0.0255 & -0.0574 \\
0 & $0.0086^{* * *}$ & 0.0223 & 2.8741 & -0.0009 & 0.0244 & -0.2777 \\
$(0,1)$ & $0.0144^{* * *}$ & 0.0343 & 3.1478 & 0.0034 & 0.0353 & 0.7240 \\
$(0,2)$ & $0.0127^{* *}$ & 0.0395 & 2.4084 & 0.0043 & 0.0455 & 0.7149 \\
$(0,3)$ & $0.0133^{* *}$ & 0.0430 & 2.3194 & 0.0086 & 0.0503 & 1.2958 \\
$(0,4)$ & $0.0119^{*}$ & 0.0507 & 1.7591 & 0.0111 & 0.0499 & 1.6841 \\
$(0,5)$ & 0.0105 & 0.0495 & 1.5831 & 0.0083 & 0.0472 & 1.3265 \\
\hline
\end{tabular}

Note: ${ }^{*}, * * * *$ significance at the $10 \%, 5 \%, 1 \%$ significance level.

firmed by the findings reached for the average cumulative abnormal returns.

The average cross-sectional cumulative abnormal returns $(C \bar{A} R)$ around dividend announcement day turns out to be statistically significant in the daily intervals $(0,1),(0,2),(0,3)$ and $(0,4)$, whereas all the average cross-sectional cumulative abnormal returns calculated within the eleven days long event window around the dividend payment day are statistically insignificant.

The behavior of the cumulative abnormal returns in the window $(-5,+5)$ days around the dividend announcement day and the dividend payment day are illustrated on Graph 1 and Graph 2, respectively.

Considering the frequent occurrence of non-normal distribution of abnormal returns, the significance of obtained results is verified by conducting the nonparametric Corrado rank test and the generalized sign test. The summary of findings is presented in Table 4 .

The results of the Corrado test generally corroborate the previous findings. Abnormal returns significantly different from zero occur on the days $t=0$ in the case of the dividend announcement and do not occur in any case of the dividend payment. All abnormal returns in the event window around the dividend payment day are independent across the stocks examined. The proportion of positive returns is found to be significantly lower than $50 \%$ on the day $t=-2$ in the event window around the dividend payment day.

Table 5 contains the values of abnormal returns calculated for the three subsamples described in section 4 . The values of Shapiro-Wilk statistics with p-values indicate the legitimacy of using either parametric or nonparametric significance tests.

In the case of the average cross-sectional abnormal returns for the 18 first announced dividends (or dividends announced after a minimum one-year-break), the only one significant average abnormal return is found on the day $t=+1(0.90 \%, 5 \%$ level, nonparametric test). Since the series of abnormal returns for all the days of the event window turn out not to be normally distributed, the usage of the Corrado test is justified.

In the case of the 13 dividend decreases, the significant average abnormal returns (at the 10\% level) 


\section{CAR $(-5,+5)$ around dividend announcement day $(\mathrm{N}=56)$}

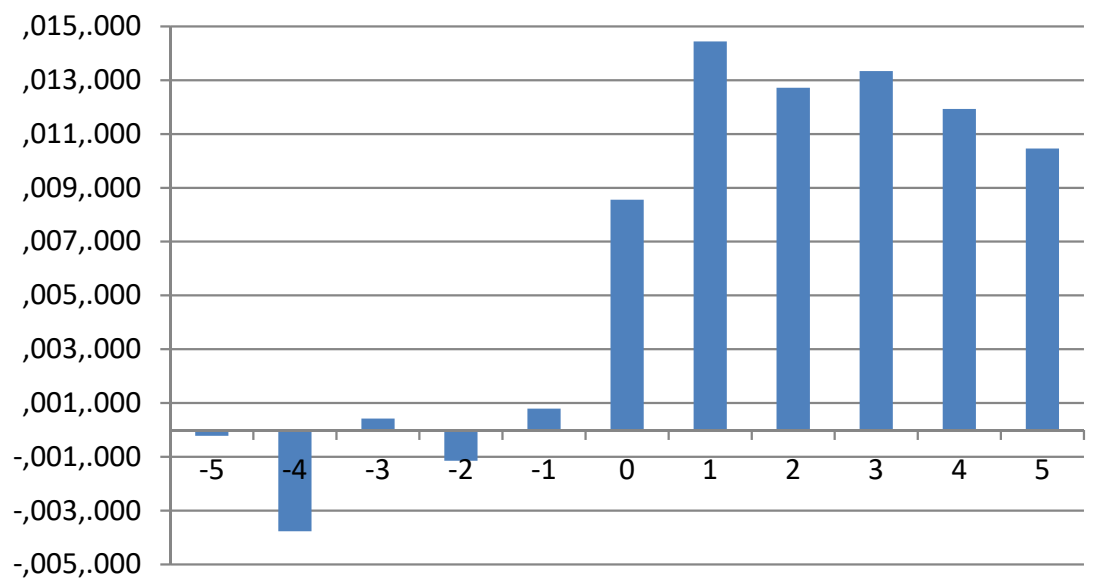

Graph 1. Cumulative abnormal returns in the window $(-5,+5)$ days around the dividend announcement day

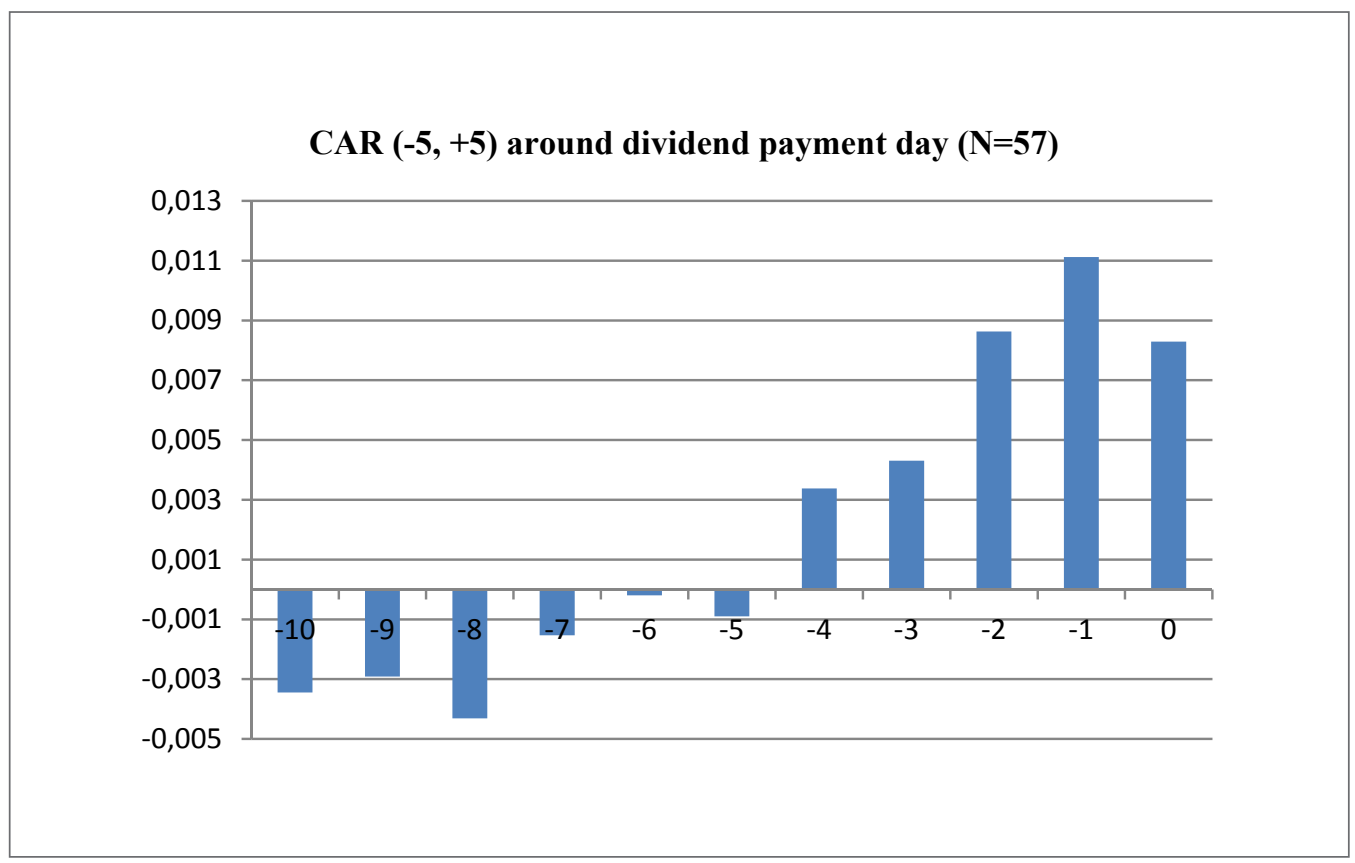

Graph 2. Cumulative abnormal returns in the window $(-5,+5)$ days around the dividend payment day 
Table 4. Results of Corrado test and the generalized sign test

\begin{tabular}{cccccccccccc}
\hline day $\boldsymbol{t}$ & $\mathbf{- 5}$ & $\mathbf{- 4}$ & $\mathbf{- 3}$ & $\mathbf{- 2}$ & $\mathbf{- 1}$ & $\mathbf{0}$ & $\mathbf{1}$ & $\mathbf{2}$ & $\mathbf{3}$ & $\mathbf{4}$ & $\mathbf{5}$ \\
\hline $\mathrm{T}(\mathrm{u})^{\mathrm{a}}$ & 0.46 & -1.56 & 0.08 & -1.28 & 1.01 & $2.32^{* *}$ & 1.35 & -0.55 & -0.89 & -0.17 & -0.80 \\
$\mathrm{~T}(\mathrm{u})^{\mathrm{b}}$ & -0.80 & 1.17 & -0.42 & -0.46 & -0.67 & -0.42 & 0.50 & -0.17 & 1.26 & 0.96 & -0.96 \\
$\mathrm{z}^{\mathrm{a}}$ & 0.27 & -0.53 & 0.80 & $-2.14^{* *}$ & 0.80 & 1.07 & 0.80 & 0.27 & -1.07 & 0.80 & -0.53 \\
$\mathrm{z}^{\mathrm{b}}$ & -1.19 & -0.13 & 0.13 & -0.13 & -1.46 & -0.66 & 0.92 & -0.13 & 1.46 & 0.13 & -0.66 \\
\hline
\end{tabular}

Note: ${ }^{* *}$ - significance at the $5 \%$ significance level, $T(u)$ - statistic for Corrado test (equation 6 ), z - statistic for generalized sign test (equation 8), ${ }^{a}$ - event day equals to dividend announcement day, ${ }^{b}$ - event day equals to dividend payment day.

Table 5. Average daily abnormal returns around the dividend announcement day in three subsamples - the results of parametric and nonparametric tests

\begin{tabular}{|c|c|c|c|c|c|c|c|c|c|c|c|c|c|c|c|}
\hline \multirow[b]{2}{*}{$\begin{array}{c}\text { day } \\
t\end{array}$} & \multicolumn{5}{|c|}{ A } & \multicolumn{5}{|c|}{ B } & \multicolumn{5}{|c|}{ C } \\
\hline & $A \bar{R}_{t}$ & SW stat. & $\mathrm{p}$-value & t stat. & $\mathrm{T}(\mathrm{u})$ & $A \bar{R}_{t}$ & SW stat. & $\mathrm{p}$-value & t stat. & $T(u)$ & $A \bar{R}_{t}$ & SW stat. & $\mathrm{p}$-value & t stat. & $T(u)$ \\
\hline-5 & 0.0022 & $0.267^{* * *}$ & 0.000 & 0.2979 & -0.5217 & 0.0063 & 0.905 & 0.155 & 0.8124 & 0.6139 & 0.0049 & 0.970 & 0.770 & 0.9048 & 1.0435 \\
\hline-4 & -0.0048 & $0.266^{* * *}$ & 0.000 & -0.8278 & -0.7454 & $-0.0144^{*}$ & $0.874^{*}$ & 0.059 & -1.8838 & -1.6664 & 0.0006 & 0.944 & 0.307 & 0.0738 & -0.6708 \\
\hline-3 & -0.0015 & $0.273^{* * *}$ & 0.000 & -0.2487 & -0.5963 & 0.0001 & 0.901 & 0.138 & 0.0212 & 0.0000 & 0.0044 & $0.874^{* *}$ & 0.017 & 0.8502 & 0.2236 \\
\hline-2 & 0.0023 & $0.301^{* * *}$ & 0.000 & 0.3184 & -0.2981 & -0.0029 & $0.827^{* *}$ & 0.015 & -0.7209 & -0.7894 & -0.0021 & $0.892^{* *}$ & 0.034 & -0.5108 & -0.3727 \\
\hline-1 & 0.0000 & $0.396^{* * *}$ & 0.000 & -0.0031 & 0.1491 & -0.0004 & 0.961 & 0.763 & -0.0760 & 0.6139 & 0.0010 & $0.854^{* * *}$ & 0.008 & 0.2299 & 0.7454 \\
\hline 0 & 0.0092 & $0.835^{* * *}$ & 0.004 & 1.4170 & 1.2671 & 0.0065 & 0.916 & 0.222 & 1.1721 & 0.7016 & 0.0077 & 0.972 & 0.811 & 1.5617 & 0.5217 \\
\hline 1 & $0.0090^{* *}$ & ${ }^{*} 0.354^{* * *}$ & 0.000 & 1.3093 & 2.2361 & 0.0019 & 0.940 & 0.463 & 0.3320 & 0.5262 & $0.0103^{*}$ & $0.885^{* *}$ & 0.027 & 1.9544 & 0.2981 \\
\hline 2 & 0.0027 & $0.287^{* * *}$ & 0.000 & 0.4753 & 0.0745 & $-0.0115^{*}$ & 0.952 & 0.626 & -2.0571 & -1.7541 & -0.0018 & $0.858^{* * *}$ & 0.009 & -0.4896 & -0.2236 \\
\hline 3 & -0.0010 & $0.275^{* * *}$ & 0.000 & -0.1523 & -1.0435 & 0.0045 & $0.877^{*}$ & 0.066 & 0.5367 & 0.9648 & 0.0004 & $0.857^{* * *}$ & 0.009 & 0.0691 & -1.2671 \\
\hline 4 & -0.0038 & $0.262^{* * *}$ & 0.000 & -0.7526 & -0.5217 & -0.0029 & 0.939 & 0.443 & -0.5373 & -0.2631 & 0.0026 & 0.943 & 0.300 & 0.4956 & 1.2671 \\
\hline 5 & 0.0027 & $0.259^{* * *}$ & 0.000 & 0.5387 & 0.0000 & 0.0023 & $0.849 * *$ & 0.027 & 0.4290 & 1.0525 & -0.0053 & 0.832 & 0.832 & -1.5221 & -1.5652 \\
\hline $\mathrm{N}$ & & & 18 & & & & & 13 & & & & & 19 & & \\
\hline
\end{tabular}

Note: $\mathrm{A}$ - first dividend/dividend resumes after a break, B - dividend decreases, $\mathrm{C}$ - dividend increases, ${ }^{*},{ }^{* *},{ }^{* * *}-$ significance at the $10 \%, 5 \%, 1 \%$ significance level.

are found on the days $t=-4(-1.44 \%)$ and $t=+2$ $(-1.15 \%)$. The decision of the statistical significance is made based on either parametric or nonparametric significance test due to the normality of distribution of analyzed abnormal returns time series.

The average abnormal returns for the 19 announced dividend increases turn out to be positive and significant on the day $t=+1 \quad(1.03 \%, 10 \%$ level, parametric test). However, this result should be treated with caution, since the abnormal returns on the day $t=+1$ are not normally distributed at the $10 \%$ significance level.

Table 6 contains summarized values of the average cumulative abnormal returns around the dividend announcement day calculated for the three selected subsamples. 
Table 6. Statistical significance of the average cumulative abnormal returns $(C \bar{A} R s)$ around the dividend announcement day in three subsamples

\begin{tabular}{|c|c|c|c|c|c|c|c|c|c|}
\hline \multirow[b]{2}{*}{$\left(t_{1}, t_{2}\right)$} & \multicolumn{3}{|c|}{ A } & \multicolumn{3}{|c|}{ B } & \multicolumn{3}{|c|}{$C$} \\
\hline & $C \bar{A} R$ & $\hat{\sigma}\left(C A R_{t}\right)$ & t-stat & $C \bar{A} R$ & $\hat{\sigma}\left(C A R_{t}\right)$ & t-stat & $C \bar{A} R$ & $\hat{\sigma}\left(C A R_{t}\right)$ & t-stat \\
\hline$(-5,0)$ & 0.0089 & 0.0741 & 0.5208 & -0.0113 & 0.0437 & -0.9317 & -0.0017 & 0.0593 & -0.1244 \\
\hline$(-4,0)$ & 0.0039 & 0.0653 & 0.2608 & $-0.0176^{* *}$ & 0.0269 & -2.3559 & -0.0040 & 0.0515 & -0.3280 \\
\hline$(-3,0)$ & 0.0033 & 0.0404 & 0.3600 & -0.0032 & 0.0306 & -0.3754 & 0.0009 & 0.0483 & 0.0755 \\
\hline$(-2,0)$ & -0.0011 & 0.0274 & -0.1768 & -0.0033 & 0.0278 & -0.4277 & 0.0023 & 0.0523 & 0.1879 \\
\hline$(-1,0)$ & 0.0010 & 0.0182 & 0.2299 & -0.0004 & 0.0181 & -0.0760 & 0.0000 & 0.0402 & -0.0031 \\
\hline 0 & 0.0077 & 0.0214 & 1.5617 & 0.0065 & 0.0199 & 1.1721 & 0.0092 & 0.0277 & 1.4170 \\
\hline$(0,1)$ & $0.0179^{* *}$ & 0.0348 & 2.2467 & 0.0084 & 0.0316 & 0.9573 & $0.0183^{*}$ & 0.0387 & 2.0053 \\
\hline$(0,2)$ & $0.0162^{* *}$ & 0.0311 & 2.2654 & -0.0032 & 0.0352 & -0.3231 & $0.0210^{*}$ & 0.0499 & 1.7835 \\
\hline$(0,3)$ & 0.0165 & 0.0448 & 1.6086 & 0.0014 & 0.0299 & 0.1667 & 0.0200 & 0.0521 & 1.6282 \\
\hline$(0,4)$ & 0.0191 & 0.0553 & 1.5036 & -0.0015 & 0.0349 & -0.1574 & 0.0162 & 0.0606 & 1.1327 \\
\hline$(0,5)$ & 0.0138 & 0.0540 & 1.1141 & 0.0008 & 0.0320 & 0.0873 & 0.0189 & 0.0581 & 1.3799 \\
\hline $\mathrm{N}$ & & 18 & & & 13 & & & 19 & \\
\hline
\end{tabular}

Note: A - first dividend/dividend resumes after a break, B - dividend decreases, $\mathrm{C}$ - dividend increases,

* ${ }^{* *}$ - significance at the $10 \%, 5 \%$ significance level.

The results of the average cumulative abnormal returns' analysis confirm - in most cases - the findings obtained for the average cross-sectional abnormal returns. The reaction of the market is statistically significant in the daily intervals $(0,1)$ and $(0,2)$, either in the case of the first dividend (dividend resumes after a break) announcement (1\% significance level) or in the case of dividend-increase announcements (10\% significance level). In the case of dividend-decrease announcements the average cumulative abnormal returns remain statistically insignificant. Therefore, the results obtained for cumulative abnormal returns in the subgroup of dividend decreases stay in contrast to the findings reached for the average abnormal returns (compare Table 5).

The presented results generally stay in line with the other studies conducted on the Polish stock market. In comparison to Gurgul and Majdosz (2005), a positive and statistically significant market reaction appears already on the day of the dividend announce- ment. However, unlike Tuzimek (2013), the authors do not obtain significant mean cross-sectional abnormal returns on the day before the announcement. The effects of the announcements in the distinguished subsamples, namely, first dividend announcement or dividend resumption, dividend cut and dividend increase, stay in line with the theoretical predictions. The average abnormal returns for dividend initiations and increases are positive in sign, and the results are comparable with Czekaj (2014) and Tuzimek (2013). Unlike Tuzimek (2013), the present findings indicate the expected negative impact on stock prices in the case of dividend cuts. However, as in the Tuzimek study (2013), the findings obtained for dividend decreases are statistically significant at the $10 \%$ significance level.

The obtained results are generally in line with US and European studies (Dasilas \& Leventis, 2011; i.e., Gurgul et al., 2003; Lonie et al., 1996), which proves the existence of the dividend announcement signal- 
ing effect not only in the case of the news release that promises investors an increasing dividend.

\section{Summary and conclusions}

The results obtained based on 56 dividend announcements among companies listed on the WSE in the year 2013 are mixed. Based upon the sample of 56 firms, the market reaction turns out to be statistically significant and positive only on the dividend announcement day and one day after the announcement. The mean cross abnormal returns are found to be insignificantly different from zero for all ten days around the dividend payment day. Thus, the effect of dividend announcement is reflected in stock prices immediately.

Considering the direction of changes in the expected dividend payouts, in the case of increasing dividends and dividends paid for the first time (or dividend resumes after a break), the impact of the news release on stock prices is statistically significant, positive and noticed on the first day after the announcements. Furthermore, in the case of dividend decrease announcements, their impact on stock prices is negative and noticeable on the second day after the announcement.

The outcomes of the study allow us to confirm that the effect of dividend announcements is in line with the informational content of the dividend hypothesis as well as with dividend signaling models. The reaction of the market is consistent with the direction of the dividend change: dividend-increase (-decrease) announcements are interpreted as a positive (negative) signal by the investors. Moreover, the stock market reaction on the news release turns out to be rather quick. Thus, the prices seem to 'digest' the information immediately. Based on the employed sample the authors cannot confirm that behavioral models of dividends have a good explanatory power in the case of the Polish stock market. The reaction of the stock prices, although correct in sign, has not been stronger in the case of dividend cuts compared to dividend increases.

Finally, the authors would like to add two general remarks. First, the Polish stock market is not semi-strong informationally efficient in a given period. However, it is pertinent to note that the observed abnormal market behavior disappears within two days at most after the announcement date. Second, the obtained results can be useful for financial practitioners. The statistical significance of abnormal returns in response to dividend announcements can be used to build portfolios with dividend companies. However, the profitability of such portfolios should be checked in a long-term period, which is beyond the scope of this study.

\section{References:}

Aharony, J., \& Swary, I. (1980). Quarterly dividend and earning announcements and stockholders' returns: An empirical analysis. The Journal of Finance, 35(1), 1-12.

Al-Shattarat, W. K., Al-Khasawneh J. A., \& Al-Shattarat, H. K. (2012). Market reaction to changes in dividend payments policy in Jordan. The Journal of Applied Business Research, 28(6), 1193-1210.

Asquith, P., \& Mullins, D. W. (1983). The impact of initiating dividend payments on shareholders' wealth. The Journal of Business, 56(1), 77-96.

Baker, H. K., Powell, G. E., \& Veit, E. T. (2002). Revisiting the dividend puzzle: Do all the pieces fit now? Review of Financial Economics, 11(4), 241-261.

Baker, M., \& Wurgler, J. (2004). A catering theory of dividends. The Journal of Finance, 59(3), 11251165.

Baker, M., \& Wurgler, J. (2012). Dividends as reference points: A behavioral signaling approach (Working Paper Series No. 18242). National Bureau of Economic Research. Retrieved from http://www.nber. org/papers/w18242.pdf

Bhattacharya, S. (1979). Imperfect information, dividend policy, and 'the bird in the hand' fallacy. The Bell Journal of Economics, 10(1), 259-270.

Boehmer, E., Masumeci, J., \& Poulsen, A. B. (1991). Event-study methodology under conditions of event-induced variance. Journal of Financial Economics, 30(2), 253-272.

Brown, S. J., \& Warner, J. B. (1980). Measuring security price performance. Journal of Financial Economics, 8(3), 205-258.

Charitou, A., Lambertides, N., \& Theodoulou, G. (2011). Losses, dividend reductions, and market reaction associated with past earnings and dividends patterns. Journal of Accounting, Auditing and Finance, Forthcoming, 26(2), 351-382.

Chowdhury, G., \& Miles, D. K. (1989). Modelling companies' debt and dividend decisions with company accounts data. Applied Economics, 21(11), 1483-1508. 
Corrado, Ch. J. (1989). A nonparametric test for abnormal security-price performance in event studies. Journal of Financial Economics, 23(2), 385-395.

Cowan, A. R. (1992). Nonparametric event study tests. Review of Quantitative Finance and Accounting, 2(4), 343-358.

Czekaj, J. (2014). Efektywność półsilna [Semi-strong efficiency]. In J. Czekaj (Ed.), Efektywność giełdowego rynku akcji $w$ Polsce $z$ perspektywy dwudziestolecia [The efficiency of the stock market in Poland in the perspective of twenty years] (pp. 91-134). Warszaw: Polskie Wydawnictwo Ekonomiczne.

Dasilas, A., \& Leventis, S. (2011). Stock market reaction to dividend announcements: Evidence from the Greek stock market. International Review of Economics and Finance, 20(2), 302-311.

DeAngelo, H., DeAngelo, L., \& Skinner, D. J. (1992). Dividends and losses. The Journal of Finance, 47(5), 1837-1863.

Dhillon, U. S., \& Johnson, H. (1994). The effect of dividend changes on stock and bond prices. The Journal of Finance, 49(1), 281-289.

Easterbrook, F. H. (1984). Two agency costs explanations of dividends. American Economic Review, 74(4), 650-659.

Forbes, W. (2009). Behavioral finance. Chichester, UK: John Wiley \& Sons.

Gajdka, J. (2013). Behawioralne finanse przedsiębiorstw. Podstawowe podejścia i koncepcje [Behavioral corporate finance. Basic approaches and concepts]. Łódź: Wydawnictwo Uniwersytetu Łódzkiego.

Gordon, M. (1959). Dividends, earnings and stock prices. The Review of Economics and Statistics, 41(2), 99-105.

Grullon, G., Michaely, R., \& Swaminathan, B. (2002). Are dividends changes a sign of firm maturity? Journal of Business, 75(3), 387- 424.

Gurgul, H. (2012). Analiza zdarzeń na rynkach akcji. Wpływ informacji na ceny papierów wartościowych [Event study on stock markets. Impact of information on the securities prices] (2nd ed.). Warszaw: Wolters Kluwer Polska.

Gurgul, H., \& Majdosz, P. (2005). Effect of dividend and repurchase announcement on the Polish stock market. Badania Operacyjne i Decyzje, 1 , 25-41.
Gurgul, H., Mestel, R., \& Schleicher, Ch. (2003). Stock market reactions to dividend announcements: Empirical evidence from the Austrian stock market. Financial Markets and Portfolio Management, 17(3), 332-350.

Janicka, M. (2005). Polski rynek kapitałowy - powstanie rozwój i perspektywy w strukturach jednolitego rynku finansowego Unii Europejskiej [Polish capital market - foundation, development and prospects within the structures of the single European financial market]. Ekonomista, 5, 673-689.

Jensen, M. C. (1986). Agency costs of free cash flow, corporate finance and takeovers. The American Economic Review, 76(2), 323-329.

Jensen, M. C., \& Meckling, W. H. (1976). Theory of the firm: Managerial behavior, agency costs and ownership structure. Journal of Financial Economics, 3(4), 305-360.

John, K., \& Williams J. (1985). Dividends, dilution, and taxes: A signalling equilibrium. The Journal of Finance, 40(4), 1053-1070.

Kahneman, D., \& Tversky, A. (1979). Prospect theory: An analysis of decision under risk. Econometrica, 47(2), 263-292.

Kowerski, M. (2011). Ekonomiczne uwarunkowania decyzji o wypłatach dywidend przez spótki publiczne [The economic determinants of the dividend payout decisions of public companies]. KrakówRzeszów-Zamość: Wydawnictwo Konsorcjum Akademickie.

Lintner, J. (1956). Distribution of incomes of corporations among dividends, retained earnings, and taxes. The American Economic Review, 46(2), 97-113.

Lintner, J. (1962). Dividends, earnings, leverage, stock prices and the supply of capital to corporations. The Review of Economics and Statistics, 44(3), 243-269.

Lonie, A. A., Abeyratna, G., Power, D. M., \& Sinclair C. D. (1996). The stock market reaction to dividend announcements: A UK study of complex market signals. Journal of Economic Studies, 23(1), 32-52.

McCluskey, T., Burton, B. M., Power, D. M., \& Sinclair, C.D. (2006). Evidence on the Irish stock market's reaction to dividend announcements. Applied Financial Economics, 16(8), 617-628. 
Miller, M. H., \& Rock, K. (1985). Dividend policy under asymmetric information. The Journal of Finance, 40(4), 1031-1061.

Miller, M. H., \& Modigliani, F. (1961). Dividend policy, growth, and the valuation of shares. The Journal of Business, 34(4), 411-433.

Mrzygłód, U., \& Nowak, S. (2013). Stock exchanges go public: The case of Warsaw stock exchange. Journal of International Studies, 6(2), 111-123.

Myers, S. C., \& Majluf, N. S. (1984). Corporate financing and investment decisions when firms have information that investors do not have. Journal of Financial Economics, 13(2), 187-221.

Ofer, A. R., \& Thakor, A. V. (1987). A theory of stock price responses to alternative corporate cash disbursement methods: Stock repurchases and dividends. The Journal of Finance, 42(2), 365-394.

Perepeczo, A. (2013). Reakcja akcjonariuszy na decyzje o wypłacie dywidendy w spółkach publicznych - wyniki badań empirycznych [Market reactions to dividend announcements in public companies - empirical evidence]. In K. Jajuga, W. Ronka- Chmielowiec (Eds.), Prace Naukowe Uniwersytetu Ekonomicznego we Wrocławiu, Inwestycje finansowe i ubezpieczenia - tendencje światowe a rynek polski [Research Papers of Wrocław University of Economics, Financial Investments and Insurance - Global Trends and the Polish Market] (pp. 253-264). Wrocław: Wydawnictwo Uniwersytetu Ekonomicznego we Wrocławiu.

Perepeczo, A. (2014). Reakcja inwestorów na decyzje o wypłacie dywidendy a kryzys finansowy [The reaction of investors to changes in the dividend policy and the financial crisis]. In A. Kopiński, A. Bem (Eds.), Prace Naukowe Uniwersytetu Ekonomicznego we Wrocławiu, Zarzadzanie finansami firm - teoria i praktyka [Research Papers of Wrocław University of Economics, Financial Management - Theory and Practice] (pp. 184-195). Wrocław: Wydawnictwo Uniwersytetu Ekonomicznego we Wrocławiu.

Pettit, R. R. (1972). Dividend announcements, security performance, and capital market efficiency. The Journal of Finance, 27(5), 993-1007.

Pieloch-Babiarz, A. (2014). Wysokość pieniężnych wypłat dywidendy a kształtowanie się kursu giełdowego akcji spółek w pierwszym dniu notowań 'bez dywidendy' [Amount of cash dividend payments and the 'ex-dividend' day return's formation]. In A. Kopiński, A. Bem (Eds.), Prace Naukowe Uniwersytetu Ekonomicznego we Wrocławiu, Zarzadzanie finansami firm - teoria $i$ praktyka [Research Papers of Wrocław University of Economics, Financial Management - Theory and Practice] (pp. 196-208). Wrocław: Wydawnictwo Uniwersytetu Ekonomicznego we Wrocławiu.

Shefrin, H. M., \& Statman M. (1984). Explaining investors preferences for cash dividends. Journal of Financial Economics, 13(2), 253-282.

Tabak, D. I., \& Dunbar, F. C. (1999). Materiality and magnitude: Event studies in the courtroom (Working Paper No. 34). National Economic Research Associates. Retrieved from http://www. nera.com/content/dam/nera/publications/archive1/3841.pdf

Tversky, A., \& Kahneman, D. (1992). Advances in prospect theory: Cumulative representation of uncertainty. Journal of Risk and Uncertainty, 5(4), 297-323.

Tuzimek, R. (2012). Wpływ wypłat dywidendy na wartość akcji spółek notowanych na Giełdzie Papierów Wartościowych w Warszawie [Effect of dividend payments on the value of shares listed on the Warsaw Stock Exchange]. In K. Jajuga, W. Ronka- Chmielowiec (Eds.), Prace Naukowe Uniwersytetu Ekonomicznego we Wrocławiu, Inwestycje finansowe $i$ ubezpieczenia - tendencje światowe a rynek polski [Research Papers of Wrocław University of Economics, Financial Investments and Insurance - Global Trends and the Polish Market] (pp. 333-346). Wrocław: Wydawnictwo Uniwersytetu Ekonomicznego we Wrocławiu.

Tuzimek, R. (2013). Efektywność decyzji dotyczących wypłat na rzecz właścicieli [The effectiveness of decisions regarding distribution to owners]. In R. Tuzimek (Ed.), Decyzje finansowe w spółkach giełdowych a wartość akcji [Financial decisions of companies listed on the stock exchange and the value of shares] (pp. 275-315). Warszaw: Oficyna Wydawnicza Szkoły Głównej Handlowej.

Yoon, P. S., \& Starks, L. T. (1995). Signaling, investment opportunities, and dividend announcements. The Review of Financial Studies, 8(4), 995-1018. 
Vieira, E. S., \& Raposo, C. C. (2007). Signalling with dividends? New evidence from Europe. Available at http://ssrn.com/abstract $=1004523$

Ziarko-Siwek, U. (2008). Giełda papierów wartościowych w Polsce - Giełda Papierów Wartościowych w Warszawie S.A [Stock exchange in Poland - The Warsaw Stock Exchange]. In U. Ziarko-Siwek (Ed.), Giełdy kapitałowe w Europie [Stock exchanges in Europe] (pp. 347-374). Warszaw: CeDeWu Sp. z o.o. 